\title{
Faunal Diversity of Ajmer Aravalis Lepidoptera Moths
}

\author{
Dr Rashmi Sharma \\ Dept. Of Zoology, SPC GCA, Ajmer, Rajasthan, India
}

\begin{abstract}
Ajmer is located in the center of Rajasthan (INDIA) between $25^{\circ} 38$ " and $26^{\circ} 58$ "North 75
0 22" East longitude covering a geographical area of about $8481 \mathrm{sq} . \mathrm{km}$ hemmed in all sides by Aravalli hills. About 7 miles from the city is Pushkar Lake created by the touch of Lord Brahma. The Dargah of khawaja Moinuddin chisti is holiest shrine next to Mecca in the world. Ajmer is abode of certain flora and fauna that are particularly endemic to semi-arid and are specially adapted to survive in the dry waterless region of the state. Lepidoptera integument covered with scales forming colored patterns. Availability of moths were more during the nights and population seemed to be Confined to the light areas. Moths are insects with 2 pair of broad wings covered with microscopic scales drably coloured and heldflat when at rest. They do not have clubbed antennae. They are nocturnal. Atlas moth is the biggest moth.
\end{abstract}

Keywords: Ajmer, Faunal diversity, Lepidoptera, Moths, Aravalis.

\section{Introduction}

Ajmer is located in the center of Rajasthan (INDIA) between $25^{0} 38$ " and $26^{0} 58$ " North Latitude and $73^{\circ} 54$ " and $75^{\circ} 22^{\prime}$ " East longitude covering a geographical area of about 8481sq km hemmed in all sides by Aravalli hills. About 7 miles from the city is Pushkar Lake created by the touch of lord Brahma. The Dargah of khawaja Moinuddin chisti is holiest shrine next to Mecca in the world. Ajmer is abode of certain flora and fauna that are particularly endemic to semi-arid and are specially adapted to survive in the dry waterless region of the state. Lepidoptera integument covered with scales forming colored patterns. Availability of moths were more during the Rainy season. Nocturnal insectivores feed on moth such as bats, owls, birds, lizards, cats, dogs, rodents, and bears. Baculoviruses (Baculoviridae a family that is restricted to insects) are parasites double stranded DNA insect viruses and are used as biological control agents. Moths use technique of celestial navigation called transverse orientation they maintain a constant angular relationship to a bright celestial light. They can fly in a straight light. The present study reveals that 41 families and 56 Species. Noctuidae were the first to emerge (March) and Sphingidae was the most late arrival emerging in the month April. The peak moth activity was observed in the month of July (Rainy season).

\section{Methodology}

Field observations were made during March to April and September to November in different areas of Ajmer East, West, North and South AJMER with varied habitats like gardens, hilly areas parks mountains, vegetable areas, open fields, agricultural areas and other cultivated areas.

\section{Observations and Results}

During the course of present field investigations about 56 species of moths distributed under 41 families. The detail of Family, name of species and common name are given below. Noctuidae was found to be most dominant family. Followed by Geometridae. Some species were found in all months except extreme winters i.e. march to October, November, others were restricted in distribution only in September October Some species were quick fliers, others were shy in nature. The present study reveals that 41 families and 56 Species. Noctuidae were the first to emerge (March) and Sphingidae was the most late arrival emerging in the month April. The peak moth activity was observed in the month of July (Rainy season).
1. Alucitidae
2. Arctiidae
3. Bombycidae
4. Brachodidae
5. Brahmaeidae
6. Choreutidae
7. Cosmopterigidae
8. Cossidae 
9. Crambidae

10. Drepanidae

11. Eupterotidae

12. Gelechiidae

13. Geometridae

14. Glyphipterigidae

15. Graccillariidae

16. Hepialidae

17. Immidae

18. Lasiocampidae

19. Lecithoceridae

20. Limacodidae

21. Lymantriidae

22. Noctuidae

23. Nolidae

24. Notodontidae

25. Oecophoridae

26. Pantheidae

27. 27.Peleopodidae

28. 28.Phaudidae

29. Psychidae

30. Pterophoridae

31. Pyralidae

32. Saturniidae

33. Sessiidae

34. Sphingidae

35. Thyrididae

36. Tineidae

37. Tortricidae

38. Uranidae

39. Xyloryctidae

40. Yponomeutidae

41. Zygaenidae

Table 1 Moths of AJMER

\begin{tabular}{|c|c|c|c|c|}
\hline S. No. & Family/Scientific name & $\mathrm{M}$ & Abundance & Habitat \\
\hline 1 & Alucitidae & & & \\
\hline 2 & $\begin{array}{l}\text { Arctiidae (Tiger moths): Lithosia luridiola, } \\
\text { (Common footman), Spilarctia lutea, S. } \\
\text { Oblique.Spilosoma lubricipedia (White Ermine). Utetheisa } \\
\text { pulchelloides salt and pepper moth actively feeding } \\
\text { on flowers and grass during day time. }\end{array}$ & Rs & $\mathrm{C}$ & $\mathrm{T}$ \\
\hline 3 & $\begin{array}{l}\text { Bombycidae True silk moths, mulberry silkmoths(native } \\
\text { to China). B. horsfieldi. }\end{array}$ & Rs & $\mathrm{C}$ & $\mathrm{T}$ \\
\hline 4 & Brachodidae & & & \\
\hline 5 . & $\begin{array}{l}\text { Brahmaeidae - Brahmaea wallichii Brahmin moths of } \\
\text { India. }\end{array}$ & Rs & $\mathrm{C}$ & $\mathrm{T}$ \\
\hline 6 & $\begin{array}{l}\text { Choreutidae-Metal mark moths. Choriutis cothurnata. } \\
\text { Tebenna micalis, }\end{array}$ & M & $\mathrm{C}$ & $\mathrm{T}$ \\
\hline 7. & $\begin{array}{l}\text { Cosmopterigidae Cosmet moth, narrow wings, tiny } \\
\text { larvae.Native to Australia. }\end{array}$ & & & \\
\hline 8 & $\begin{array}{c}\text { Cossidae native to north America Acossus } \\
\text { centerensis. }\end{array}$ & $M$ & $C$ & $T$ \\
\hline 9 & Crambidae Ostrinia nubilalus stem borer. & Rs & $\mathrm{F}$ & $\mathrm{T}$ \\
\hline 10. & $\begin{array}{l}\text { Drepanidae (Thyratirids hook tips ) Drapana } \\
\text { falcataria. }\end{array}$. & $\mathrm{M}$ & $\mathrm{C}$ & $\mathrm{T}$ \\
\hline 11. & $\begin{array}{l}\text { Eupterotidae : Eupterote undulate Pectinate antennae } \\
\text { lack proboscis and tympanum. Also recorded from } \\
\text { India }\end{array}$ & Rs & $\mathrm{C}$ & $\mathrm{T}$ \\
\hline 12. & $\begin{array}{l}\text { Gelechiidae- Dichomeris heriguronsis, D. summate, D. } \\
\text { Resitella, Meteoritis religiosa, Pectinophora gossypiella } \\
\text { (pink bullworm). Demopractis tonaea,Carbatima } \\
\text { picrocarpa.Phthorimaea operculella (Potato tube moth). }\end{array}$ & $\mathrm{Rs}$ & $\mathrm{C}$ & $\mathrm{T}$ \\
\hline 13. & $\begin{array}{l}\text { Geometridae: Cosymbia punctaria } \text { (Maiden's Blush). } \\
\text { Euphyia bilineata ,( (Yellow } \quad \text { shell), Gonodontis }\end{array}$ & $\mathrm{Rs}$ & $\mathrm{C}$ & $\mathrm{T}$ \\
\hline
\end{tabular}




\begin{tabular}{|c|c|c|c|c|}
\hline & bidentata (Scalloped Hazel). & & & \\
\hline 15. & $\begin{array}{l}\text { Graccillariidae - Acrocercops allactopa, Barboryctis } \\
\text { triplaca, Caloptilla acinata,Calybites phasianipennella. }\end{array}$ & Rs & $\mathrm{C}$ & $\mathrm{T}$ \\
\hline 16. & Hepialidae (Swifts) Hepialus lupulima Common swift. & Rs & $\mathrm{C}$ & $\mathrm{T}$ \\
\hline 17. & Immidae & $\mathrm{M}$ & $\mathrm{C}$ & $\mathrm{T}$ \\
\hline 18. & Lasiocampidae (Eggars) Lasiocampa quercus). & Rs & $\mathrm{C}$ & $\mathrm{T}$ \\
\hline 19. & Lecithoceridae & $\mathrm{M}$ & $\mathrm{C}$ & $\mathrm{T}$ \\
\hline 20. & Limacodidae & & & \\
\hline 21. & Lymantriidae (Tussocks )Vapourer (Orgyia antique). & Rs & $\mathrm{C}$ & $\mathrm{T}$ \\
\hline 22. & $\begin{array}{l}\text { Noctuidae(Noctuas). - Agrotis segetum(Turnip moth), } \\
\text { A. Exclamationis (Heart and Dart).Araeopteron } \\
\text { fasciale, A. Griseata. Acronicta pruinosa. Naenia } \\
\text { typica (The Goliath).Mamestra brassicae (Cabbage } \\
\text { moth).Hadena rivularis (The Campion). Malacosoma } \\
\text { Neustria. }\end{array}$ & $M$ & $C$ & $T$ \\
\hline 23. & Nolidae & & & \\
\hline 24. & $\begin{array}{l}\text { Notodontidae (Prominents)- Antheua liparidioides. A. } \\
\text { servula. Pterostoma palpina (pale prominent). } \\
\text { Lophopteryx capucina (Coxcomb Prominent). }\end{array}$ & Rs & $\mathrm{C}$ & $\mathrm{T}$ \\
\hline 25. & Oecophoridae & & & \\
\hline 26. & Pantheidae & & & \\
\hline 27. & Peleopodidae & & & \\
\hline 28. & Phaudidae & & & \\
\hline 29. & Psychidae - Eumeta crameri & Rs & $\mathrm{C}$ & $\mathrm{T}$ \\
\hline 30. & $\begin{array}{l}\text { Pterophoridae- Calyciphora sesamitis Amblyptilia } \\
\text { forcipata. Adela viridella. }\end{array}$ & Rs & $\mathrm{C}$ & $\mathrm{T}$ \\
\hline 31. & $\begin{array}{l}\begin{array}{l}\text { Pyralidae (Pyralids) Nomophila noctuella ,Pleuroptya } \\
\text { ruralis. }\end{array}\end{array}$ & Rs & $\mathrm{C}$ & $\mathrm{T}$ \\
\hline 32. & Saturniidae - Saturnia albofasciata. & Rs & $\mathrm{C}$ & $\mathrm{T}$ \\
\hline 33. & $\begin{array}{l}\text { Sessiidae - Sesia apiformis , Trilochana scolioides, } \\
\text { Melittia astarte. }\end{array}$ & Rs & $\mathrm{C}$ & $\mathrm{T}$ \\
\hline 34. & $\begin{array}{l}\text { Sphingidae - Theretra nessus, } \\
\text { (Death's head hawk moth.) }\end{array}$ & Rs & $\mathrm{C}$ & $\mathrm{T}$ \\
\hline 35. & Thyrididae - Striglina strigosa, S. scitaria. & Rs & $\mathrm{C}$ & $\mathrm{T}$ \\
\hline 36. & Tineidae - Fungus moth. & & & \\
\hline 37. & Tortricidae & & & \\
\hline 38. & Uraniidae - not present. & - & - & - \\
\hline 39. & Xyloryctidae & - & - & - \\
\hline 40. & Yponomeutidae & - & - & - \\
\hline 41. & Zygaenidae Zygena filipendulae(Burnet). & Rs & $\mathrm{C}$ & $\mathrm{T}$ \\
\hline
\end{tabular}

Rs - Resident, M- Monsoon, T-Terrestrial, C - common, F- Frequent

\section{Discussion}

During the course of present field investigation, 56 species of moths under 41 families main are viz. Arctidae, Gelechidae, Geometridae, Noctuidae, Pyrailidae. The detail list of family, name of species habitat, status, abundance is provided. Noctuidae, was found to be the most dominant family represented by 19 species, followed by Gelechidae and Geometridae. The present study revealed 41 and members of family Noctuidae were first to emerge (from march) and members of family Sphingidae were most late in emerging. The peak moth activities were observed during the months of march april july august September October incorporating all 8 families covering 41 species.

The highest Moth diversity was during Rainy season. There was no moth activity during peak summer (May, June) and peak winter (December January February). The overall moth activity was observed March April from and July august September night. Depending upon weather, month, season, host plant temperature and type of species concerned. The species of Noctuidae were found in all months and were most dominant.

\section{Conclusion}

The present field investigation revealed that district Ajmer is rich in floral and faunal Wealth. Specially in moth diversity. However its biological diversity not been documented till date. We cannot conclude that moth fauna of the area is increasing or decreasing. The area needs to be continuosly monitored and efforts be made to document its unknown floral and faunal wealth and there is need to have a vision document on the sustainable development of the district care and focus on documentation and conservation of its rich biodiversity. The Aravallis are being continuously cut for house construction and urbanization. There should be a check on the activity.

The present study revealed 41 and members of family Noctuidae were first to emerge (from march) and members of family Sphingidae were most late in emerging. The peak moth activities were observed 
during the months of march April July, August, September, October incorporating all 41 families covering 56 species. The highest Moth diversity was during Rainy season. There was no moth activity during peak summer (May, June) and peak winter (December, January, February). The overall moth activity was observed March April from and July august September night. Depending upon weather, month, season, host plant temperature and type of species concerned. The species of Noctuidae were found in all months and were most dominant. Depending upon weather, month, season, host plant temperature and type of species concerned.

\section{Acknowledgement}

We are thankful 1 to Dr J. R. B. Alfred Director Zoological Survey Of India and Dr S. Z. Siddiqui Officer in charge zoological survey of India freshwater biological station Hyderabad, for facilities editing and encouragement.

\section{References}

[1]. Barlow, H. S. and I. P. Woiwod, 1989. Mothdiversity of a tropical forest in Penninsular Malaysia J. Trop. Ecol., 5: 37-50.

[2]. Bell, T. R. D. and F. B. Scot, 1937. Fauna of BritishIndia including Ceylon and Burma. Moths. Vol.V. Sphingidae. Taylor and Francis Ltd. London.

[3]. Bell, T. R. D., 1919. The common butterflies of theplains of India (including those met within the hill stations of the Bombay Presidency). J. Bomb.Nat. Hist. Soc., 26(2): 438-487; 26(3): 750-764;26(4): 941-954.

[4]. Benton, T. G., 1995. Biodiversity and biogeography of Henderson Island insects. Biol. J. Linn. Soc.,56(1-2): 245 - 259.

[5]. Bingham, C. T., 1905. The Fauna of British-India including Ceylon and Burma. Butterflies. Vols. I and II. Taylor and Francis Ltd. London.

[6]. Bingham, C. T., 1907. The Fauna of British-India including Ceylon and Burma. Butterflies. Vols. I and II. Taylor and Francis Ltd. London.

[7]. Daniel, F., 1965. Osterreichische Entomologische Iran- Afghanistan-Expeditionen Beitrage ZurLepidopteren fauna. Zeits. Wein. Ent. Ges., 50 (9-10): 121-145.

[8]. De Niceville, L. and G. F. L. Marshall, 1886. The Butterflies of India, Burma and Ceylon. Vol. II.Calcutta Central Press Co. Ltd., Calcutta India.

[9]. Elbert, G., 1969. Afghanistan bombyces and sphinges. (Sphingidae: Lepidoptera). Lich. Mus.Tierh. Dresden, 12(5): $37-63$.

[10]. Hampson, G. F., 1894. The fauna of British India including Ceylon and Burma. Moths. Vols. I-V, London.

[11]. Holloway, J. D., 1980. Insect surveys - an approach to environmental monitoring. Atti XII Congresso Nazionale Italiano Entomologia. Roma, 1: 231- 261.

[12]. Holloway, J. D., 1984. The larger moths of the Gunung Mulu National Park; a preliminaryassessment of their distribution, ecology and potential as environmental indicators. TheSarawak Museum Journal XXX, 51: 150-191.

[13]. Holloway, J. D., 1985. Moths as indicator organisms for categorizing rain forest and monitoring changes and regeneration processes. Tropical Rain Forest: The Leeds Symposium, pp. 235- 242.

[14]. Holloway, J. D., 1987. Macrolepidoptera diversity in the Indo-Australian tropics: geographic,biotopic and taxonomic variations. Biol. J. Linn. Soc., 30:325-341.

[15]. Larsen T. B., 1987. The butterflies of the Nilgiri mountains of south India (Lepidoptera).Rhopalocera). J. Bomb. Nat. Hist. Soc., 84 (1): 26-54; 84 (2): 291-316; 84 (3): 560-584.

[16]. Mani, M. S., 1986. Butterflies of the Himalaya.

[17]. Oxford and IBH Co., New Delhi, India, $181 \mathrm{p}$.

[18]. Margalef, R., 1958. Temporal succession and spatial heterogeneity in phytoplankton. In: Perspectives in Marine biology, BuzzatiTraverso (ed.), Univ. Calif. Press, Berkeley, pp. 323-347.

[19]. Mathew, G. and V. K. Rahamathulla, 1993. Biodiversity in the Western Ghats - a study with reference to Moths (Lepidoptera: Heterocera) in the Silent Valley National Park, India. Entomon., 20(2): 25-33.

[20]. OTA (US Congress Office of Technology Assessment), 1987. Technologies to maintainbiological diversity. US Government Printing Office, Washington DC.

[21]. Pielou, E. C., 1966. The measurement of diversity in different types of biological collections. J.Theoret. Biol., 13: 131-144.

[22]. Shannon, C. E. and W. Wiener, 1949. The mathematical theory of communication. Urbana,University of Illinois Press, $177 \mathrm{p}$.

[23]. Talbot, G., 1939-1947. Fauna of British-India including Ceylon and Burma. Butterflies, Vols. Iand II. Today and Tomorrow's Printers and Publishers, New Delhi, India.

[24]. Wilson, E. O., 1992. Fluctuations in abundance of tropical insects. Amer. Nat., 112: 1017-1045. 